\title{
Influence of Organic Manures and Removal of Spikes on Corm Production of Gladiolus (Gladiolus $x$ hybrida) cv. "Priscilla"
}

\author{
A. Qureshi*, Z.A. Qadri and Rahat Wani \\ Sher-e-Kashmir University of Agricultural Sciences and Technology, Shalimar, India \\ *Corresponding author
}

\section{A B S T R A C T}

Keywords

Biodynamic compost, Gladiolus, Organic manure, Removal of spike, Vermicompost

Article Info

Accepted:

20 July 2018

Available Online:

10 August 2018
The present study on the influence of organic manures and removal of spikes on corm production of gladiolus (Gladiolus x hybrida) cv. "Priscilla" was carried out as a field experiment at SKUAST- Kashmir, Shalimar campus, Jammu and Kashmir during 201415. The experiment consists of twelve treatment combinations comprising of three different organic manures (FYM at $2.5 \mathrm{~kg} \mathrm{~m}^{-2}$, biodynamic compost i.e. Dalweed at $1.5 \mathrm{~kg}$ $\mathrm{m}^{-2}$ and vermicompost at $1 \mathrm{~kg} \mathrm{~m}^{-2}$ ) and removal of spike (10 days after spike emergence and at colour break), along with the control treatment (no organic manure and no removal of spike) replicated thrice in a Randomized Complete Block Deign. Among organic manures, treatment $\mathrm{M}_{2}$ (Biodynamic compost i.e. Dalweed at $1.5 \mathrm{~kg} \mathrm{~m}^{-2}$ ) revealed better vegetative characteristics (viz., plant height, number of leaves plant ${ }^{-1}$ and leaf area plant ${ }^{-1}$ recorded at 90 DAP; shoot dry weight and shoot RGR) and corm characteristics (corm dry weight, corm RGR, weight and diameter of the main corm plant ${ }^{-1}$, and number of corms and cormels plant ${ }^{-1}$ ). In case of removal of spike, treatment $R_{1}$ (Removal after10 days of spike emergence ) was found superior in recording maximum leaf area plant ${ }^{-1}$ at $90 \mathrm{DAP}$, corm dry weight, corm RGR, weight and diameter of main corm and number of corms and cormels plant ${ }^{-1}$.

\section{Introduction}

Gladiolus is an ornamental flowering plant of glamour and perfection. It is highly priced for its magnificent inflorescence with array of bright, beautiful and vivid colours used for cut flower production, herbaceous borders, beddings, rockeries, pots and also for indoor decoration. Very few flowering plants can match the panorama of colours and hues, shapes and sizes offered by this exquisite bulbous flowering crop. In domestic market, gladiolus surpasses any other flower although it stands next to rose production (Arora et al., 2002).

For the production of healthy and vigorous corms and cormels in gladiolus, nutritional requirement throughout the period of growth, corm development, and flowering is of utmost importance. Higher quantum of inorganic fertilizers is needed in the production of this crop and due to high cost of commercial fertilizers and poor purchasing strength of the marginal farmers, it is imperative to develop strategies for using organic manures to their 
maximum potential with appropriate technology. The use of organic manure not only improves texture, structure, humus, color, aeration, water holding capacity and microbial activity of soil but its use also aids in enhancing the vegetative growth, quality flowering and for higher yield of corms and cormels. Spike removal, in general, causes corm thickening. Late flowering varieties develop larger corms due to spike removal although spike removal has no significant effect on early flowering varieties. Spike removal just after emergence or at beginning of flowering, did not significantly affect corm yield, but doubles the yield of cormels as compared to undisturbed plants.

\section{Materials and Methods}

Influence of organic manures and removal of spike was studied on the gladiolus cv. "Priscilla" in an experiment conducted at SKUAST- Kashmir, Shalimar campus, Jammu and Kashmir, India during 2014- 15. The experiment was carried out in a Randomized Complete Block Design with three replications. The corms of uniform grade were subjected to twelve treatment combinations of the Organic manures and Removal of spike i.e. $\mathrm{T}_{1}$ - Control [No manure + No removal of spike], $\mathrm{T}_{2}$ [No manure + Removal of spike after 10 days of appearance], $\mathrm{T}_{3}$ [No manure + Removal of spike at colour break], $\mathrm{T}_{4}$ [Farm Yard Manure (FYM) at $2.5 \mathrm{~kg} \mathrm{~m}^{-2}+$ No removal of spike], $\mathrm{T}_{5}$ [FYM at $2.5 \mathrm{~kg} \mathrm{~m}^{-2}+$ Removal of spike after 10 days of appearance], $\mathrm{T}_{6}$ [FYM at $2.5 \mathrm{~kg} \mathrm{~m}^{-2}+$ Removal of spike at colour break], $\mathrm{T}_{7}$ [Biodynamic compost (Dalweed) at $1.5 \mathrm{~kg} \mathrm{~m}^{-2}+$ No removal of spike], $\mathrm{T}_{8}$ [Biodynamic compost (Dalweed) at $1.5 \mathrm{~kg} \mathrm{~m}^{-}$ ${ }^{2}+$ Removal of spike after 10 days of appearance], $\mathrm{T}_{9}$ [Biodynamic compost (Dalweed) at $1.5 \mathrm{~kg} \mathrm{~m}^{-2}+$ Removal of spike at colour break], $\mathrm{T}_{10}$ [Vermicompost at $1 \mathrm{~kg}$ $\mathrm{m}^{-2}+$ No removal of spike], $\mathrm{T}_{11}$
[Vermicompost at $1 \mathrm{~kg} \mathrm{~m}^{-2}+$ Removal of spike after 10 days of appearance] and $\mathrm{T}_{12}$ [Vermicompost at $1 \mathrm{~kg} \mathrm{~m}^{-2}+$ Removal of spike at colour break]. Recommended intercultural operations were followed to raise healthy gladiolus crop.

Data like plant height, number of leaves plant $^{-1}$ and leaf area plant ${ }^{-1}$, shoot dry weight plant $^{-1}$, corm dry weight plant ${ }^{-1}$, weight and diameter of the main corm plant ${ }^{-1}$, total weight of the corms and cormels plant $^{-1}$, number of corms and cormels plant ${ }^{-1}$, and propagation coefficient were calculated. Relative growth rate of shoot and corm were estimated using the following formula:

$\left.\mathrm{RGR}=\frac{\left(\log \mathrm{w}_{2}\right.}{\mathrm{t}_{2}-\mathrm{t}_{1}}-\log \mathrm{w}_{1}\right) \times 2.303$

where,

$\mathrm{w}_{1}=$ dry weight of shoot $/$ corm plant ${ }^{-1}$ at time $\mathrm{t}_{1}$

$\mathrm{w}_{2}=$ dry weight of shoot $/$ corm plant $^{-1}$ at time $\mathrm{t}_{2}$

The experimental data were subjected to statistical analysis and the variation among the treatment means was tested for significance by analysis of variance techniques as described by Gomez and Gomez (1984) for Randomized Complete Block Design (RCBD).

\section{Results and Discussion}

\section{Effect of organic manures and removal of spike on vegetative characteristics}

As shown in Table -1 , treatment $\mathrm{M}_{2}$ recorded maximum plant height $(67.33 \mathrm{~cm})$, number of leaves plant ${ }^{-1}$ (8.35) and leaf area plant $^{-1}\left(54.09 \mathrm{~cm}^{2}\right)$ measured at 90 DAP. Whereas, minimum plant height $(52.48 \mathrm{~cm})$, number of leaves plant ${ }^{-1}(6.05)$ and Leaf area plant $^{-1}\left(36.88 \mathrm{~cm}^{2}\right)$ was registered by control treatment $\mathrm{M}_{0}$. Significant differences were 
observed on the effect of the organic manures on shoot dry weight recorded at different intervals. At 75 DAP, maximum and minimum shoot dry weight was revealed by treatment $\mathrm{M}_{3} \quad(6.54 \mathrm{~g})$ and $\mathrm{M}_{0} \quad(5.13$ g).Treatment $\mathrm{M}_{2}$ recorded maximum shoot dry weight for 90 DAP (9.97 g) and 105 DAP $(15.84 \mathrm{~g})$, whereas, minimum shoot dry weight 6.84 and $9.02 \mathrm{~g}$ was recorded by $\mathrm{M}_{0}$ (control) for 90 and 105 DAP, respectively. At 120 DAP shoot dry weight had shown a decreasing trend but maximum and minimum values were retained by treatment $\mathrm{M}_{3}$ (12.64 g) and $\mathrm{M}_{0}(7.75 \mathrm{~g})$. Regarding shoot RGR, treatment $\mathrm{M}_{2}$ recorded significantly maximum values for growth interval 75- 90 DAP (0.027 $\left.\mathrm{g} \mathrm{g}^{-1} \mathrm{day}^{-1}\right)$ and 91- 105 DAP $\left(0.028 \mathrm{~g} \mathrm{~g}^{-1} \mathrm{day}^{-1}\right)$. However, minimum shoot RGR 0.016 and $0.019 \mathrm{~g} \mathrm{~g}^{-1}$ day $^{-1}$ was recorded for the growth intervals 75- 90 and 91- 105 DAP by treatment $\mathrm{M}_{0}$, respectively. The organic manures increase the availability of nutrients to plants. By the utilization of these nutrients, plants show increase in the leaf number, leaf size and leaf area resulting in increased accumulation of dry matter in the leaves. The results are in conformity with the findings of Pradeep et al (2014), Gajbhiye et al (2013); and Gangadharan and Gopinath (2000) who have reported significant influence of organic manures on plant height, number of leaves plant ${ }^{-1}$ and leaf area plant $^{-1}$ in different cultivars of gladiolus.

Removal of spike had no significant effect on the plant height and number of leaves plant $^{-1}$ recorded at 90DAP. The findings revealed that at 90DAP, treatment $\mathrm{R}_{1}\left(49.95 \mathrm{~cm}^{2}\right)$ and $\mathrm{R}_{0}\left(41.71 \mathrm{~cm}^{2}\right)$ registered maximum and minimum leaf area plant $^{-1}$. Significantly maximum shoot dry weight 5.96, 8.41 and $12.28 \mathrm{~g}$ was recorded with $\mathrm{R}_{0}$ at 75,90 and 105 DAP, respectively. Minimum shoot dry weight was registered by treatment $\mathrm{R}_{1}$ for 75 DAP (4.39 g), 90 DAP (5.66 g) and 105 DAP $(7.53 \mathrm{~g})$. However the increasing trend in recording shoot dry weight declined at 120 DAP interval, $\mathrm{R}_{0}(9.58 \mathrm{~g})$ and $\mathrm{R}_{1}(5.99 \mathrm{~g})$ recording maximum and minimum values of shoot dry weight. The shoot RGR was found maximum by treatment $R_{0}$ for the growth intervals 75- 90 DAP $\left(0.028 \mathrm{~g} \mathrm{~g}^{-1}\right.$ day $\left.^{-1}\right)$ and 90- 105 DAP (0.027 $\left.\mathrm{g} \mathrm{g}^{-1} \mathrm{day}^{-1}\right)$. However, the minimum shoot RGR (0.016 and $0.019 \mathrm{~g}$ $\mathrm{g}^{-1}$ day $^{-1}$ ) was recorded under treatment $R_{1}$ for the growth intervals 75-90 DAP and 91- 105 DAP. The probable cause of improvement in vegetative characteristics may be that the plants which received the treatment (removal of the spike) lead to the loss of larger photosynthetic part of the plant, thus removal of spike might result in decreased shoot dry matter, which eventually decreases the shoot RGR in comparison to the plants where no spike was removed. Also, the elimination of floral sink increases translocation of photosynthates to growing bulbs (Jhon and Khan, 2003), thus the photosynthates that accumulate in the bulb, encourage the increase in leaf area.

\section{Interaction effect of Organic manures and Removal of spike on vegetative characteristics}

Table- 2 reveals that there was no significant effect of the interaction of organic manures and removal of spike on plant height, number of leaves plant ${ }^{-1}$ and leaf area plant ${ }^{-1}$. With regard to shoot dry weight, initially at 75 and 90 DAP, there was no significant interaction effect of organic manures and removal of spike. However, the treatment combination $\mathrm{T}_{7}\left(\mathrm{M}_{2} \times \mathrm{R}_{0}\right)$ recorded significantly maximum shoot dry weight 24.26 and $21.16 \mathrm{~g}$ at 105 and 120 DAP, respectively. However, minimum shoot dry weight 6.49 and $5.68 \mathrm{~g}$ was recorded at 105 and 120 DAP by treatment combination $\mathrm{T}_{2}\left(\mathrm{M}_{0} \times \mathrm{R}_{1}\right)$. The findings revealed that significantly maximum (0.035 $\left.\mathrm{g} \mathrm{g}^{-1} \mathrm{day}^{-1}\right)$ and minimum $\left(0.018 \mathrm{~g} \mathrm{~g}^{-1}\right.$ day $^{-1}$ ) shoot RGR was recorded under 
treatment combinations $\mathrm{T}_{7}\left(\mathrm{M}_{2} \times \mathrm{R}_{0}\right)$ and $\mathrm{T}_{2}$ $\left(\mathrm{M}_{0} \times \mathrm{R}_{1}\right)$ for growth interval 91- 105 DAP.

\section{Effect of organic manures and removal of spike on corm characteristics}

Results revealed that organic manures significantly influenced the weight and diameter of main corm, as well as the number of corms and cormels plant ${ }^{-1}$ of gladiolus cv. "Priscilla" (Table- 3). Significantly maximum weight of main corm plant $^{-1}(61.21 \mathrm{~g})$, diameter of main corm plant $^{-1}(6.80 \mathrm{~cm})$, number of corms plant ${ }^{-1}$ (2.44) and number of cormels plant ${ }^{-1}$ (36.67) was recorded under treatment $\mathrm{M}_{2}$. However, minimum weight of main corm plant ${ }^{-1}(35.33 \mathrm{~g})$, diameter of main corm plant $^{-1}(5.71 \mathrm{~cm})$, number of corms plant $^{-1}$ (1.04) and number of cormels plant ${ }^{-1}$ (19.33) was registered by control treatment, $\mathrm{M}_{0}$. The findings revealed that treatment $\mathrm{M}_{2}$ recorded maximum corm dry weight for the growth periods of 75 DAP $(8,83 \mathrm{~g}), 90$ DAP $(12.46 \mathrm{~g}), 105$ DAP (18.87 g) and 120 DAP $(26.07 \mathrm{~g})$. However, minimum values of corm dry weight (4.63, 5.97, 7.84 and $10.14 \mathrm{~g}$ ) were recorded by treatment $\mathrm{M}_{0}$ for the growth intervals of $75,90,105$ and 120 DAP, respectively.

Significantly maximum corm RGR was recorded for 75- 90 DAP $\left(0.022 \mathrm{~g} \mathrm{~g}^{-1}\right.$ day $\left.^{-1}\right)$, 91- 105 DAP (0.026 g g day $\left.^{-1}\right)$ and 106- 120 DAP (0.021 $\mathrm{g} \mathrm{g}^{-1}$ day $\left.^{-1}\right)$ under treatment $\mathrm{M}_{2}$, whereas minimum corm RGR was recorded by $\mathrm{M}_{0}$ for growth interval 75- 90 DAP $(0.016$ $\mathrm{g} \mathrm{g}^{-1}$ day $\left.^{-1}\right)$, 91- 105 DAP (0.018 $\mathrm{g} \mathrm{g}^{-1}$ day $\left.^{-1}\right)$ and 106- 120 DAP (0.016 $\left.\mathrm{g} \mathrm{g}^{-1} \mathrm{day}^{-1}\right)$. Organic manures are rich source of nutrients which ensure improved vegetative and corm growth that eventually increased the dry matter accumulation in corms. The results of the present study are in concurrence with the findings of numerous researchers (Kumari et al., 2014, Pradeep et al., 2014, Jha et al., 2012, Godse et al., 2006, and Gangadharan and Gopinath, 2000), who achieved increased weight and diameter of corms plant ${ }^{-1}$ as well as number of corms and cormels plant ${ }^{-1}$ in response to application of organic manures while working on different cultivars of gladiolus. Apart from gladiolus, similar results were reported by Srivastava et al. (2014) in tuberose cv. "Shringar".

As shown in Table-3, removal of spike significantly influenced most of the corm characteristics of gladiolus cv. "Priscilla". However, weight and diameter of main corm was not significantly influenced by removal of spike. Significantly more number of corms (2.58) and cormels (38.92) were recorded by treatment $R_{1}$, and significantly less number of corms (1.42) and cormels (20.25) were registered under treatment $R_{0}$. Significantly superior corm dry weight was recorded by treatment $\mathrm{R}_{1}$ for 75 DAP $(8.59 \mathrm{~g}), 90 \mathrm{DAP}$ (12.51 g), 105 DAP (18.35 g) and 120 DAP (25.32 g). However, minimum corm dry weight $(5.22,6.54,8.53$ and $10.83 \mathrm{~g}$ ) was recorded by treatment $\mathrm{R}_{0}$ for $75,90,105$ and 120 DAP. The findings revealed that maximum corm RGR for the growth intervals 75-90 DAP (0.022 $\mathrm{g} \mathrm{g}^{-1} \mathrm{day}^{-1}$ ), 91- 105 DAP $\left(0.024 \mathrm{~g} \mathrm{~g}^{-1}\right.$ day $\left.^{-1}\right)$ and 106- 120 DAP (0.021 $\mathrm{g} \mathrm{g}^{-1}$ day $^{-1}$ ) was registered by treatment $R_{1}$, whereas minimum corm RGR $(0.014,0.017$ and $0.015 \mathrm{~g} \mathrm{~g}^{-1} \mathrm{day}^{-1}$ ) was reported under treatment $\mathrm{R}_{0}$ for 75-90 DAP, 91-105 SAP and 106-120 DAP, respectively. The removal of one of the two major sinks of the plant resulted in the translocation of all the dry matter into the corms, that otherwise would have been consumed for flower growth and development, thus resulting in increased corm dry weight as compared to control. The increase in number of corms plant $^{-1}$ may be a result of more resource allocation to the underground sink which could have otherwise been used by the developing flowers (Wang and Breen, 1984). 
Table.1 Effect of organic manure and removal of spike on the vegetative characteristics of gladiolus (Gladiolus x hybrida) cv. "Priscilla"

\begin{tabular}{|c|c|c|c|c|c|c|c|c|c|c|}
\hline \multirow[t]{2}{*}{ Treatments* } & \multirow{2}{*}{$\begin{array}{l}\text { Plant } \\
\text { height } \\
(\mathrm{cm})\end{array}$} & \multirow{2}{*}{$\begin{array}{l}\text { Number } \\
\text { of } \\
\text { leaves }\end{array}$} & \multirow{2}{*}{$\begin{array}{l}\text { Leaf } \\
\text { area } \\
\left(\mathrm{cm}^{2}\right)\end{array}$} & \multicolumn{4}{|c|}{ Shoot dry weight } & \multicolumn{3}{|c|}{ Shoot RGR } \\
\hline & & & & $\begin{array}{l}75 \\
\text { DAP }\end{array}$ & $\begin{array}{l}90 \\
\text { DAP }\end{array}$ & $\begin{array}{l}105 \\
\text { DAP }\end{array}$ & $\begin{array}{l}120 \\
\text { DAP }\end{array}$ & $\begin{array}{l}75- \\
90 \\
\text { DAP }\end{array}$ & $\begin{array}{l}91- \\
105 \\
\text { DAP }\end{array}$ & $\begin{array}{l}\text { 106- } \\
120 \\
\text { DAP }\end{array}$ \\
\hline \multicolumn{11}{|c|}{ Organic manures } \\
\hline $\mathrm{M}_{0}$ & 52.48 & 6.05 & 36.88 & 5.13 & 6.84 & 9.02 & 7.75 & 0.018 & 0.019 & $\begin{array}{l}- \\
0.010\end{array}$ \\
\hline $\mathrm{M}_{1}$ & 64.78 & 7.58 & 43.57 & 6.07 & 8.57 & 12.23 & 10.33 & 0.021 & 0.023 & - \\
\hline $\mathrm{M}_{2}$ & 67.33 & 8.35 & 54.09 & 6.51 & 9.97 & 15.84 & 12.64 & 0.027 & 0.028 & - \\
\hline $\mathrm{M}_{3}$ & 65.41 & 8.22 & 47.32 & 6.54 & 9.45 & 13.71 & 10.88 & 0.023 & 0.024 & 0.016 \\
\hline $\begin{array}{l}\text { C.D } \\
(p \leq 0.05)\end{array}$ & 5.26 & 1.13 & 5.23 & 0.78 & 1.26 & 1.19 & 1.92 & 0.004 & 0.004 & N. S \\
\hline \multicolumn{11}{|c|}{ Removal of spike } \\
\hline $\mathrm{R}_{0}$ & 64.36 & 7.50 & 41.71 & 7.83 & 12.06 & 18.29 & 15.64 & 0.028 & 0.027 & $-\overline{0.016}$ \\
\hline $\mathrm{R}_{1}$ & 61.75 & 7.55 & 49.95 & 4.39 & 5.66 & 7.53 & 5.99 & 0.016 & 0.019 & $\begin{array}{l}- \\
0.009\end{array}$ \\
\hline $\mathrm{R}_{2}$ & 61.39 & 7.61 & 44.73 & 5.96 & 8.41 & 12.28 & 9.58 & 0.022 & 0.025 & $-\overline{0}$ \\
\hline $\begin{array}{l}\text { C.D } \\
(\mathbf{p} \leq \mathbf{0 . 0 5})\end{array}$ & N.S & N.S & 4.53 & 0.67 & 1.09 & 1.03 & 1.06 & 0.003 & 0.004 & N.S \\
\hline
\end{tabular}

*Treatments [Organic manures: $\mathrm{M}_{0^{-}}$No manure, $\mathrm{M}_{1^{-}}$FarmYard Manure @ $2.5 \mathrm{~kg} \mathrm{~m}^{-2}, \mathrm{M}_{2^{-}}$Biodynamic compost/ Dalweed @1.5 kg m ${ }^{-2}$ and $\mathrm{M}_{3^{-}}$Vermicompost @1 $\mathrm{kg}^{-}$ ${ }^{2}$;Removal of spike: $\mathrm{R}_{0^{-}}$- No removal, $\mathrm{R}_{1}$ - Removal after 10 days of spike emergence and $\mathrm{R}_{2}$ - Removal of spike at color break] 
Table.2 Interaction effect of organic manures and removal of spike on the vegetative characteristics of gladiolus (Gladiolus x hybrida) cv. "Priscilla"

\begin{tabular}{|c|c|c|c|c|c|c|c|c|c|c|}
\hline \multirow[t]{2}{*}{$\begin{array}{l}\text { Treatment } \\
\text { combinations }\end{array}$} & \multirow{2}{*}{$\begin{array}{l}\text { Plant } \\
\text { height } \\
(\mathrm{cm})\end{array}$} & \multirow[t]{2}{*}{$\begin{array}{l}\text { Number of } \\
\text { leaves plant }\end{array}$} & \multirow{2}{*}{$\begin{array}{l}\text { Leaf } \\
\text { Area } \\
\left(\mathrm{cm}^{2}\right)\end{array}$} & \multicolumn{4}{|c|}{ Shoot dry weight (g) } & \multicolumn{3}{|c|}{$\begin{array}{l}\text { Shoot RGR } \\
\left(\mathrm{g} \mathrm{g}^{-1} \text { day }^{-1}\right)\end{array}$} \\
\hline & & & & $\begin{array}{l}75 \\
\text { DAP }\end{array}$ & $\begin{array}{l}90 \\
\text { DAP }\end{array}$ & $\begin{array}{l}105 \\
\text { DAP }\end{array}$ & $\begin{array}{l}120 \\
\text { DAP }\end{array}$ & $\begin{array}{l}\text { 75- } 90 \\
\text { DAP }\end{array}$ & $\begin{array}{l}\text { 91-105 } \\
\text { DAP }\end{array}$ & $\begin{array}{l}\text { 106- } \\
120 \\
\text { DAP }\end{array}$ \\
\hline $\mathrm{T}_{1}\left(\mathrm{M}_{0} \times \mathrm{R}_{0}\right)$ & 55.27 & 4.71 & 34.33 & 6.51 & 9.41 & 12.15 & 10.28 & 0.024 & 0.020 & -0.011 \\
\hline $\mathrm{T}_{2}\left(\mathrm{M}_{0} \times \mathrm{R}_{1}\right)$ & 51.60 & 6.19 & 40.73 & 4.00 & 4.88 & 6.49 & 5.68 & 0.013 & 0.018 & -0.008 \\
\hline $\mathrm{T}_{3}\left(\mathrm{M}_{0} \times \mathrm{R}_{2}\right)$ & 50.67 & 7.27 & 35.57 & 4.87 & 6.23 & 8.42 & 7.29 & 0.016 & 0.019 & -0.010 \\
\hline $\mathrm{T}_{4}\left(\mathrm{M}_{1} \times \mathrm{R}_{0}\right)$ & 64.13 & 7.62 & 39.63 & 8.24 & 12.50 & 17.96 & 15.12 & 0.028 & 0.024 & -0.011 \\
\hline $\mathrm{T}_{5}\left(\mathrm{M}_{1} \times \mathrm{R}_{1}\right)$ & 66.03 & 7.31 & 47.01 & 3.86 & 4.89 & 6.51 & 5.71 & 0.015 & 0.019 & -0.009 \\
\hline $\mathrm{T}_{6}\left(\mathrm{M}_{1} \times \mathrm{R}_{2}\right)$ & 64.17 & 7.80 & 44.06 & 6.10 & 8.34 & 12.25 & 10.16 & 0.021 & 0.026 & -0.011 \\
\hline $\mathrm{T}_{7}\left(\mathrm{M}_{2} \times \mathrm{R}_{0}\right)$ & 68.07 & 8.53 & 48.32 & 8.87 & 14.30 & 24.26 & 21.16 & 0.032 & 0.035 & -0.022 \\
\hline $\mathrm{T}_{8}\left(\mathrm{M}_{2} \times \mathrm{R}_{1}\right)$ & 67.97 & 8.47 & 62.39 & 4.76 & 6.46 & 8.58 & 6.31 & 0.020 & 0.019 & -0.011 \\
\hline $\mathrm{T}_{9}\left(\mathrm{M}_{2} \times \mathrm{R}_{2}\right)$ & 65.97 & 8.04 & 51.55 & 5.91 & 9.14 & 14.68 & 10.46 & 0.029 & 0.031 & -0.022 \\
\hline $\mathrm{T}_{10}\left(\mathrm{M}_{3} \times \mathrm{R}_{0}\right)$ & 69.97 & 9.13 & 44.57 & 7.73 & 12.03 & 18.81 & 15.99 & 0.030 & 0.030 & -0.020 \\
\hline $\mathrm{T}_{11}\left(\mathrm{M}_{3} \times \mathrm{R}_{1}\right)$ & 61.40 & 8.22 & 49.68 & 4.94 & 6.40 & 8.55 & 6.25 & 0.017 & 0.019 & -0.009 \\
\hline $\mathrm{T}_{12}\left(\mathrm{M}_{3} \times \mathrm{R}_{2}\right)$ & 64.87 & 7.33 & 47.73 & 6.94 & 9.02 & 13.77 & 10.46 & 0.024 & 0.022 & -0.019 \\
\hline C.D $(\mathbf{p} \leq \mathbf{0 . 0 5})$ & N.S & N.S & N.S & N.S & N.S & 2.07 & 3.32 & N.S & 0.007 & N.S \\
\hline
\end{tabular}


Table.3 Effect of organic manure and removal of spike on the corm characteristics of gladiolus (Gladiolus x hybrida) cv. "Priscilla"

\begin{tabular}{|c|c|c|c|c|c|c|c|c|c|c|c|}
\hline \multirow[t]{2}{*}{ Treatments* } & \multirow{2}{*}{$\begin{array}{l}\text { Weight } \\
\text { of main } \\
\text { corm }(\mathrm{g})\end{array}$} & \multirow{2}{*}{$\begin{array}{l}\text { Diameter } \\
\text { of main } \\
\text { corm }(\mathrm{cm})\end{array}$} & \multirow{2}{*}{$\begin{array}{l}\text { No. of } \\
\text { corms }\end{array}$} & \multirow{2}{*}{$\begin{array}{l}\text { No. of } \\
\text { cormels }\end{array}$} & \multicolumn{4}{|c|}{ Corm dry weight (g) } & \multicolumn{3}{|c|}{ Corm RGR $\left(\mathrm{g} \mathrm{g}^{-1}\right.$ day $\left.^{-1}\right)$} \\
\hline & & & & & $\begin{array}{l}75 \\
\text { DAP }\end{array}$ & $\begin{array}{l}90 \\
\text { DAP }\end{array}$ & $\begin{array}{l}105 \\
\text { DAP }\end{array}$ & $\begin{array}{l}120 \\
\text { DAP }\end{array}$ & $\begin{array}{l}75-90 \\
\text { DAP }\end{array}$ & $\begin{array}{l}91- \\
105 \\
\text { DAP }\end{array}$ & $\begin{array}{l}106- \\
120 \\
\text { DAP }\end{array}$ \\
\hline \multicolumn{12}{|c|}{ Organic manures } \\
\hline $\mathrm{M}_{0}$ & 35.35 & 5.71 & 1.04 & 19.33 & 4.63 & 5.97 & 7.84 & 10.14 & 0.016 & 0.018 & 0.016 \\
\hline $\mathrm{M}_{1}$ & 51.47 & 6.01 & 2.07 & 29.78 & 6.33 & 8.18 & 10.93 & 14.13 & 0.017 & 0.019 & 0.016 \\
\hline $\mathrm{M}_{2}$ & 61.21 & 6.80 & 2.44 & 36.67 & 8.83 & 12.46 & 18.87 & 26.07 & 0.022 & 0.026 & 0.021 \\
\hline $\mathrm{M}_{3}$ & 58.15 & 6.38 & 2.11 & 32.78 & 6.35 & 9.39 & 12.98 & 17.55 & 0.018 & 0.021 & 0.019 \\
\hline $\begin{array}{l}\text { C.D } \\
(\mathbf{p} \leq \mathbf{0 . 0 5})\end{array}$ & 6.50 & 0.50 & 0.28 & 2.60 & 0.55 & 1.01 & 1.52 & 2.53 & 0.002 & 0.002 & 0.002 \\
\hline \multicolumn{12}{|c|}{ Removal of spike } \\
\hline $\mathrm{R}_{0}$ & 47.58 & 5.93 & 1.42 & 20.25 & 5.22 & 6.54 & 8.53 & 10.83 & 0.014 & 0.017 & 0.015 \\
\hline $\mathrm{R}_{1}$ & 54.41 & 6.52 & 2.58 & 38.92 & 8.59 & 12.51 & 18.35 & 25.32 & 0.022 & 0.024 & 0.021 \\
\hline $\mathrm{R}_{2}$ & 52.20 & 6.21 & 1.75 & 29.75 & 5.79 & 7.95 & 11.08 & 11.47 & 0.018 & 0.021 & 0.019 \\
\hline $\begin{array}{l}\text { C.D } \\
(p \leq \mathbf{0 . 0 5})\end{array}$ & N S & $\mathbf{N S}$ & 0.24 & 2.25 & 0.48 & 0.87 & 1.31 & 2.19 & 0.002 & 0.002 & 0.002 \\
\hline
\end{tabular}

*Treatments [Organic manures: $\mathrm{M}_{0^{-}}$No manure, $\mathrm{M}_{1}$ - FarmYard Manure @ $2.5 \mathrm{~kg} \mathrm{~m}{ }^{-2}, \mathrm{M}_{2}$ - Biodynamic compost/ Dalweed $1.5 \mathrm{~kg}$ $\mathrm{m}^{-2}$ and $\mathrm{M}_{3}$ - Vermicompost @ $1 \mathrm{~kg} \mathrm{~m}^{-2}$; Removal of spike: $\mathrm{R}_{0^{-}}$No removal, $\mathrm{R}_{1}$ - Removal after 10 days of spike emergence and $\mathrm{R}_{2}-$ Removal of spike at color break] 
Table.4 Effect interaction of organic manure and removal of spike on the corm characteristics of gladiolus (Gladiolus x hybrida) cv. "Priscilla"

\begin{tabular}{|c|c|c|c|c|c|c|c|c|c|c|c|}
\hline \multirow{2}{*}{$\begin{array}{l}\text { Treatment } \\
\text { combinations }\end{array}$} & \multirow{2}{*}{$\begin{array}{l}\text { Weight of } \\
\text { main } \\
\text { corm }(g)\end{array}$} & \multirow{2}{*}{$\begin{array}{l}\text { Diameter of } \\
\text { main corm } \\
(\mathrm{cm})\end{array}$} & \multirow{2}{*}{$\begin{array}{l}\text { No. of } \\
\text { corms }\end{array}$} & \multirow{2}{*}{$\begin{array}{l}\text { No. of } \\
\text { cormels }\end{array}$} & \multicolumn{4}{|c|}{ Corm dry weight (g) } & \multicolumn{3}{|c|}{ Corm RGR $\left(\mathrm{g} \mathrm{g}^{-1}\right.$ day $\left.^{-1}\right)$} \\
\hline & & & & & $\begin{array}{l}75 \\
\text { DAP }\end{array}$ & $\begin{array}{l}90 \\
\text { DAP }\end{array}$ & $\begin{array}{l}105 \\
\text { DAP }\end{array}$ & $\begin{array}{l}120 \\
\text { DAP }\end{array}$ & $\begin{array}{l}75-90 \\
\text { DAP }\end{array}$ & $\begin{array}{l}91- \\
105 \\
\text { DAP }\end{array}$ & $\begin{array}{l}106- \\
120 \\
\text { DAP }\end{array}$ \\
\hline $\mathrm{T}_{1}\left(\mathrm{M}_{0} \times \mathrm{R}_{0}\right)$ & 32.27 & 5.38 & 1.00 & 16.33 & 3.07 & 3.69 & 4.59 & 5.63 & 0.012 & 0.015 & 0.014 \\
\hline $\mathrm{T}_{2}\left(\mathrm{M}_{0} \times \mathrm{R}_{1}\right)$ & 37.68 & 6.11 & 1.13 & 22.00 & 6.68 & 8.86 & 11.87 & 15.71 & 0.018 & 0.019 & 0.019 \\
\hline $\mathrm{T}_{3}\left(\mathrm{M}_{0} \times \mathrm{R}_{2}\right)$ & 36.13 & 5.64 & 1.00 & 19.67 & 4.13 & 5.34 & 7.06 & 9.09 & 0.017 & 0.019 & 0.017 \\
\hline $\mathrm{T}_{4}\left(\mathrm{M}_{1} \times \mathrm{R}_{0}\right)$ & 45.58 & 5.79 & 1.47 & 21.33 & 4.94 & 6.12 & 7.75 & 9.47 & 0.014 & 0.016 & 0.013 \\
\hline $\mathrm{T}_{5}\left(\mathrm{M}_{1} \times \mathrm{R}_{1}\right)$ & 55.00 & 6.37 & 2.87 & 38.00 & 8.39 & 11.23 & 15.51 & 20.88 & 0.019 & 0.022 & 0.020 \\
\hline $\mathrm{T}_{6}\left(\mathrm{M}_{1} \times \mathrm{R}_{2}\right)$ & 53.82 & 5.88 & 1.87 & 30.00 & 5.73 & 7.19 & 9.51 & 12.06 & 0.017 & 0.019 & 0.016 \\
\hline $\mathrm{T}_{7}\left(\mathrm{M}_{2} \times \mathrm{R}_{0}\right)$ & 58.17 & 6.74 & 1.67 & 24.67 & 7.74 & 9.83 & 13.28 & 17.43 & 0.016 & 0.020 & 0.018 \\
\hline $\mathrm{T}_{8}\left(\mathrm{M}_{2} \times \mathrm{R}_{1}\right)$ & 63.64 & 6.84 & 3.53 & 50.33 & 10.90 & 16.75 & 27.26 & 38.74 & 0.028 & 0.033 & 0.023 \\
\hline $\mathrm{T}_{9}\left(\mathrm{M}_{2} \times \mathrm{R}_{2}\right)$ & 61.80 & 6.81 & 2.13 & 35.00 & 7.84 & 10.79 & 16.08 & 22.04 & 0.021 & 0.027 & 0.021 \\
\hline $\mathrm{T}_{10}\left(\mathrm{M}_{3} \times \mathrm{R}_{0}\right)$ & 54.39 & 5.83 & 1.53 & 18.67 & 5.12 & 6.50 & 8.50 & 25.95 & 0.016 & 0.018 & 0.016 \\
\hline $\mathrm{T}_{11}\left(\mathrm{M}_{3} \times \mathrm{R}_{1}\right)$ & 61.32 & 6.77 & 2.80 & 45.33 & 8.41 & 13.19 & 18.76 & 25.95 & 0.021 & 0.024 & 0.022 \\
\hline $\mathrm{T}_{12}\left(\mathrm{M}_{3} \times \mathrm{R}_{2}\right)$ & 58.74 & 6.53 & 2.00 & 34.33 & 5.47 & 8.47 & 11.67 & 15.91 & 0.017 & 0.021 & 0.021 \\
\hline C.D $(p \leq 0.05)$ & N.S & N.S & 0.48 & 4.51 & N.S & N.S & 2.63 & 4.38 & N.S & 0.002 & N.S \\
\hline
\end{tabular}


The results are in harmony with those of Jhon and Khan (2003). Similar were the findings of Das (1998), who reported significantly increased corms plant $^{-1}$ in gladiolus. Also, the allocation of photosynthates to the main corm as a result of elimination of floral sink may be the probable cause of increase in number of cormels.

\section{Interaction effect of organic manures and Removal of spike on corm characteristics}

As shown in Table-4, the effect of interaction of organic manures and removal of spike was significant on number of corms and cormels plant $^{-1}$.Significantly maximum number of corms (3.53) and cormels (50.33) was recorded with treatment combination $\mathrm{T}_{8}\left(\mathrm{M}_{2}\right.$ $\mathrm{x} \mathrm{R}_{1}$ ) and minimum number of corms (1.00) and cormels (16.33) with treatment combination $\mathrm{T}_{0}\left(\mathrm{M}_{0} \times \mathrm{R}_{0}\right)$. In case of weight and diameter of main corm plant $^{-1}$, interaction effect was not significant. The findings revealed that the effect of interaction was not significant on corm dry weight for initial 75 and 90 DAP. However, maximum (27.26 and $38.74 \mathrm{~g}$ ) and minimum (4.59 and $5.63 \mathrm{~g})$ corm dry weight was recorded by treatment combinations $\mathrm{T}_{8}\left(\mathrm{M}_{2} \times \mathrm{R}_{1}\right)$ and $\mathrm{T}_{1}$ $\left(\mathrm{M}_{0} \times \mathrm{R}_{0}\right)$ for 105 and 120 DAP intervals, respectively.

Corm RGR was not significantly affected by the interaction of organic manures and removal of spike for growth intervals 75-90 and 106- 120 DAP, however, for growth interval 91- 105 DAP maximum corm RGR $\left(0.033 \mathrm{~g} \mathrm{~g}^{-1} \mathrm{day}^{-1}\right)$ and minimum RGR (0.015 $\mathrm{g} \mathrm{g}^{-1}$ day $\left.^{-1}\right)$ was registered for treatment combinations $\mathrm{T}_{8}\left(\mathrm{M}_{2} \times \mathrm{R}_{1}\right)$ and $\mathrm{T}_{0}\left(\mathrm{M}_{0} \times \mathrm{R}_{0}\right)$.

\section{References}

Arora, J. S., Misra, R. L., Singh, K., Singh, P. and Bhattacharjee, S. K.
2002.Gladiolus. All India Coordinated Research project on floriculture. Technical Bulletin. 14.

Das, T. K. 1998. Effect of stage of spike removal and potassium application on corm and cormel production of some gladiolus varieties. Indian Journal of Agronomy. 43(4): 756- 761.

Gajbhiye, B. R., Vetal, R. A., Puri, A. N. and Adsul, P. B. 2013. Response of FYM, N, P and K levels on growth and flowering of gladiolus (Gladiolus grandiflorus) cv. White Prosperity. The Journal of Rural and Agricultural Research. 13(2): 94-97.

Gangadharan, G. D., and Gopinath, G. 2000. Effects of organic and inorganic fertilizers on yield of spikes, corms, cormels and returns of gladiolus cv. White Prosperity. Karnataka Journal of Agricultural Sciences. 13(4): 937941.

Godse, S. B., Golliwar, V. J., Chopde, N., Bramhankar, K. S., and Kore, M.S. 2006. Effect of organic manures and biofertilizers with reduced doses of inorganic fertilizers on growth, yield and quality of gladiolus. Journal of Soils and Crops. 16(2): 445- 449.

Gomez, K. A. and Gomez, A. A. 1984. Statistical procedures for agricultural research $\left(2^{\text {nd }}\right.$ Ed.). John Wiley and Sons Inter Science Publication, New York. p. 80.

Jha, S., Sharma, G. L., Dikshit, S. N., Patel, K. L., Tirkey, T. and Sarnaik, D. A. 2012. Effect of vermicompost and FYM in combination with inorganic fertilizer on growth, yield and flower quality of gladiolus (Gladiolus hybridus). Journal of soils and crops. 22(2): 253- 257.

Jhon, A. Q. and Khan, F. U. 2003. Effect of flower and leaf removal on bulb production in tulip cv. Cassini. SKUAST Journal of Research. 5: 
190- 193.

Kumari, V. R., Kumar, D. P., Kumar, B. A., and Mahadevamma. 2014. Effect of nutrient management on floral and cormal parameters in gladiolus (Gladiolus hybridus L.). International Journal of Agricultural Sciences. 10(1): 15- 22.

Pradeep, K., Manivannab, K. and Kumar, S. R. 2014. Effect of organic nutrients on growth, flowering and yield of Gladiolus grandiflorus L. The Asian
Journal of Horticulture. 9: 2

Srivastava, R., Preetham, S.P., and Chand, S. 2013. Effect of organic manures and biofertilizers on vegetative, floral and post harvest attributes in tuberose (Polianthes tuberosa) var. Shringar. Asian Journal of Biological and life sciences. 3(1).

Wang, Y. T. and Breen, P. J. 1984. Respiration and weight changes of Easter lily during development. Horticultural Science. 19: 702- 703.

\section{How to cite this article:}

Qureshi, A., Z.A. Qadri and Rahat Wani. 2018. Influence of Organic Manures and Removal of Spikes on Corm Production of Gladiolus (Gladiolus x hybrida) cv. "Priscilla". Int.J.Curr.Microbiol.App.Sci. 7(08): 3318-3327. doi: https://doi.org/10.20546/ijcmas.2018.708.355 